\title{
Comparative Performance of Creatinine-Based GFR Estimation Equations in Exceptional Longevity: The Rugao Longevity and Ageing Study [Erratum]
}

\author{
Wang $\mathrm{M}$, Sun $\mathrm{X}$, Ni $\mathrm{L}$, et al. Clin Interv Aging. \\ 2020;15:733-742.
}

The authors have advised that the Funding statement was missed on page 741 of the published paper. This error was introduced by the Editorial staff during the publication process. The funding statement should read as follows:

\section{Funding}

The work in this manuscript has been performed with the support of Shanghai Science and Technology
Commission Innovation Action Plan Project No.17411950701 (Jing Chen), Shanghai Natural Science Grant No. 16ZR1449400 (Mengjing Wang), China Natural Science Grant No. 81600577 (Mengjing Wang), Shanghai Medical Leading Talents Program No.2019LJ03 (Jing Chen), and the National Key R\&D Program of China No.2018YFC 2000400, No.2018YFC 2002000 (Xiaofeng Wang).
Clinical Interventions in Aging

\section{Publish your work in this journal}

Clinical Interventions in Aging is an international, peer-reviewed journal focusing on evidence-based reports on the value or lack thereof of treatments intended to prevent or delay the onset of maladaptive correlates of aging in human beings. This journal is indexed on PubMed Central, MedLine, CAS, Scopus and the Elsevier
Bibliographic databases. The manuscript management system is completely online and includes a very quick and fair peer-review system, which is all easy to use. Visit http://www.dovepress.com/ testimonials.php to read real quotes from published authors. 